\title{
ETV6/MN1 Fusion Gene
}

National Cancer Institute

\section{Source}

National Cancer Institute. ETV6/MN1 Fusion Gene. NCI Thesaurus. Code C99678.

A fusion gene that results from a chromosomal translocation $\mathrm{t}(12 ; 22)(\mathrm{p} 13 ; \mathrm{q} 11-12)$ that fuses the 5' portion of the ETV6 gene to the 3' portion of the MN1 gene. This rearrangement is associated with both acute myeloid leukemia and refractory anemia with excess blasts. 